\title{
Growth performance of heat stressed rabbits fed diets supplemented with synthetic and organic antioxidants
}

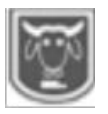

${ }^{+}$Anoh, K. U., * Barje, P. P., *Iyeghe-Erakpotobor, G. T. and ${ }^{+}$Akpa, G. N. ${ }^{+}$Department of Animal Science, Ahmadu Bello University Zaria

"National Animal Production Research Institute (NAPRI), Shika

Abstract

The aim of the study was to evaluate the growth performance of heat stressed rabbits fed diets supplemented with synthetic and organic antioxidants. The antioxidants used were bicarbonate buffers, vitamin $C$ and baobab fruit pulp meal (BFPM). A total of thirty (30) growing rabbits were used. The rabbits were allotted into the treatment groups with six (6) rabbits per treatment in a completely randomized design. Rabbits in the first group $\left(T_{1}\right)$ were the control, animals in treatment 2 and treatment $3\left(T_{2}\right)$ and $\left(T_{3}\right)$ were fed similar diets as in the control but with potassium bicarbonate $\left(\mathrm{KHCO}_{3}\right)$ and sodium bicarbonate $\left(\mathrm{NaHCO}_{3}\right)$ buffer solutions, respectively. Rabbits in treatment four $\left(T_{4}\right)$ were fed diet containing synthetic vitamin $C$ and the fifth group $\left(T_{5}\right)$ were fed diet containing Baobab Fruit Pulp Meal (BFPM). Rabbits were given access to feed and water ad libitum. All recommended managerial practices were duly observed. Microclimate parameters of ambient temperature $(A T)$ and relative humidity $(R H)$ of the rabbitry were taken daily from February through June. The values were used to calculate temperature-humidity index (THI). It was found that vitamin $C$ and BFPM significantly $(P<0.05)$ enhanced feed intake compared to the treatments with buffers. It was concluded that BFPM is more effective in ameliorating heat stress in rabbit production and can be used up to $5.5 \%$ inclusion level.

Keywords: Heat stress, growth, antioxidants, Vitamin C

\section{Introduction}

To successfully raise rabbits in a tropical country characterized with high ambient temperature like Nigeria, it is pertinent to ameliorate heat stress in rabbits. Feed intake and digestibility have been shown to reduce with increase in environmental conditions (Ayyat et al., 1996). Rabbits raised under this condition can only express their potentials of rapid growth rate and fertility when conditions are favorable. Favorable conditions must include adequate photoperiod, thermo-neutral conditions, food availability in quantity and quality as well as a low stress environment (Marai et al., 2001). Inadequate conditions may lead to a decrease in growth and reproductive capacity, varying from subfertility to infertility. This study was design to evaluate the growth performance of heat stressed rabbits fed diets supplemented with synthetic and organic antioxidants.

\section{Materials and methods Study location}

This study was carried out at the Rabbit unit of National Animal Production Research Institute (NAPRI) Shika, Zaria about 220 KM from Abuja the capital of Nigeria. Zaria has an average rain fall of $1100 \mathrm{~mm}$ which starts from late April and early May to midOctober and an average temperature of $37^{\circ} \mathrm{C}$ and average relative humidity of $75 \%$ (Ovimaps, 2014).

\section{Experimental animals and design}

A total of 25 adult rabbit bucks were used in this study. The rabbits were randomly allotted into experimental treatments of five treatment groups, with five (5) rabbits per treatment in a completely randomized design. The treatment groups consisted of: Control (Water without antioxidant), 


\section{Growth performance of heat stressed rabbits}

Potassium bicarbonate $\left(\mathrm{KHCO}_{3}\right)$, Sodium Bicarbonate $\left(\mathrm{NaHCO}_{3}\right)$, solutions, FeedVitamin $\mathrm{C}$, and BFPM as organic and synthetic anti-oxidants respectively (designated T1, T2, T3, T4 and T5 ). The water was offered ad libitum but changed daily in the morning. All rabbits were fed the same concentrate feed. All recommended managerial practices were duly observed.

Meteorological data of rabbit microclimate

The microclimate (ambient temperature and relative humidity values) within the rabbit house were recorded twice daily at 08:00 $\mathrm{h}$ and $15.00 \mathrm{~h}$ during the study period using a digital thermometer (Cocet, Shenzhen-Guangdong, China). The data collected were used to compute the temperature humidity index (THI), an indicator of the thermal comfort level of the rabbits. The THI was calculated using the modified formula for the rabbit by Marai $e t$ al. (2001) as follows:

$\mathrm{THI}=\mathrm{t}-[(0.31-0.31 \times \mathrm{RH})(\mathrm{t}-14.4)]$

Where $\mathrm{RH}=$ relative humidity $/ 100$.

$\mathrm{t}=$ ambient temperature.

The values of THI obtained were compared to that classified for tropical regions as shown

below:

$<27.8=$ Absence of heat stress, $27.8-28.9=$ Moderate heat stress, $28.9-30$ $=$ Severe heat stress and above $30=$ Very severe heat stress.

\section{Growth performance parameters}

Parameters monitored and measured on weekly basis included weight gain and feed intake, and mortality were recorded as they occurred.

\section{Statistical analysis}

Data obtained from all the experiments were subjected to analysis of variance, using the General Liner Model Procedure of SAS (2002). Significant differences among treatment means were separated using the pair wise difference (Pdiff) in the SAS package. Values of $\mathrm{P}<0.05$ were considered significant.

\section{Results and discussions}

The THI value (Fig. 1) of $27^{\circ} \mathrm{C}$ recorded in (Feb) indicated that the month of February had absence of heat stress in the rabbit house, while the THI values of $28^{\circ} \mathrm{C}$ (March and June), $29.5^{\circ} \mathrm{C}$ (April) and $31.2^{\circ} \mathrm{C}$ (May) and $28^{\circ} \mathrm{C}$ (June) were indications that the rabbit house was moderately thermallystressful, severely thermally stressful and very severely-thermally stressful, respectively (Marai, 2001) in these months. The average THI of $28.74^{\circ} \mathrm{C}$ during the experimental period indicated that the rabbit house was thermally stressful and may have adverse effects on the rabbits (Marai, 2001). Overall data obtained indicated that THI in the afternoon was higher by $1.24 \%$ than THI in the morning.

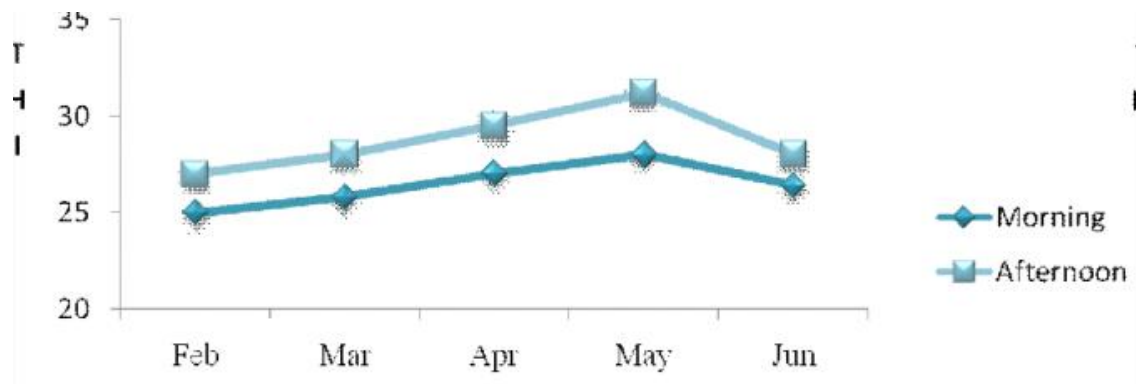

Months

Figure 1; Monthly Temperature of Humidity Index of the Pen House 


\section{Anoh, Barje, Iyeghe-Erakpotobor and Akpa}

The table below shows that heat stress declined feed intake, weight gain and overall feed efficiency. However, supplementation of antioxidants along with the basal diet significantly $(\mathrm{P}<0.05)$ improved feed intake, although other growth performance parameter did not show any significant difference. . This finding is similar to the findings of Yassein et al., (2011) and Sahin and Kucuk, (2001). The significant difference that was observed in this study by the buffers $\left(\mathrm{Na}_{2} \mathrm{CO}_{3}\right.$ and $\left.\mathrm{KHCO}_{3}\right)$, vitamin $\mathrm{C}$ and BFPM, agrees with the findings of Yassein et al. (2011), who reported that $\mathrm{Na}_{2} \mathrm{CO}_{3}$ and $\mathrm{KHCO}_{3}$ serve as appetizer supplements to rabbit's diets and may stimulate the appetite, increase fiber digestibility and improve feed efficiency. Similar results were obtained by Marai et al. (1994) that $1.25 \%$ or $2.5 \% \mathrm{NaHCO} 3$ improved growth performance, rectal temperature, respiration rate and blood components by correcting acid -base balance disturbances, such as those that occur under stress conditions. Vitamin $\mathrm{C}$ has been reported to be effective in growth performance of rabbits, especially during heat stress (Rao and Sharma 2001). Bain (1996) revealed that vitamin $\mathrm{C}$ aids conversion of protein and fat into energy for production and survivability through increased corticosteroid secretion. Vitamin C supplementation also increases performance, yield better carcass trait in broilers, reared under heat stress conditions $\left(32^{\circ} \mathrm{C}\right)$ (Sahin, and Kucuk, 2001). It has been reported that broiler chicken fed BFPM diets during hot season performed better than those fed the vitamin-C supplemented diets as well as the control diet (Adeosun, 2012). A similar trend was observed in this study. Supplementation with BFPM in diets up to $3.5 \%$ gave better performance and egg quality characteristics of layers than the control diet during the hot-dry season (Adeosun, 2012).

Effects of Bicarbonate Buffers, Vit C and BFPM on Growth Performance of Growing Rabbits

\begin{tabular}{lllllll}
\hline & \multicolumn{5}{c}{ Treatments } & SEM \\
\cline { 2 - 6 } Parameters & Control & KHCO $_{3}$ & $\mathbf{N a}_{\mathbf{2}} \mathbf{C O}_{\mathbf{3}}$ & Vit. C & BFPM & SEM \\
\hline Initial weight (g) & 866.70 & 908.30 & 833.30 & 800.00 & 800.00 & 121.88 \\
Final weight (g) & 1533.30 & 1633.90 & 1400.00 & 1345.50 & 1365.00 & 117.58 \\
Weight gain (g/day) & 13.96 & 16.99 & 14.58 & 13.37 & 15.28 & 1.82 \\
Feed intake (g/day) & $30.76^{\mathrm{b}}$ & $30.93^{\mathrm{b}}$ & $42.39^{\mathrm{a}}$ & $37.59^{\mathrm{a}}$ & $36.77^{\mathrm{a}}$ & 1.88 \\
\hline
\end{tabular}

Means within rows with different superscripts are significantly different: $\mathrm{P}<0.05$

Vit $\mathrm{C}=$ Vitamin $\mathrm{C}, \mathrm{BFPM}=$ Baobab fruit pulp meal

\section{Conclusion}

Among the antioxidants used, vitamin $\mathrm{C}$ and BFPM were more effective on growth performance of rabbits compared to bicarbonate buffers. It is recommended that antioxidants especially vitamin $\mathrm{C}$ should be included in rabbit diets during hot periods for optimum production.

\section{References}

Adeosun, S. L. 2012. Effects of Synthetic Ascorbic Acid and Baobab Fruit
Pulp Meal Supplementation as Sources of Ascorbic Acid in Layer and Broiler Diets during Cool-wet and Hot-dry seasons. Ph.D Thesis ubmitted to the Post-graduate School, Ahmadu Bello University, Zaria- Nigeria.

Ayyat, M. S. and Marai, I. F. M. 1996. Effects of heat stress on growth, carcass traits and blood components of New Zealand White rabbits fed various dietary energyfiber levels, under Egyptian 
conditions. Journal of Arid Environments 37: 557-568.

Bain, B. S. 1996. The role of Vitamin C in stress management. World's Poultry Science, 12 (4): 34-41

Marai, I. F. M., Ayyat, M. S. and Abd ElMonem, U. M. 2001. Growth performance and reproductive traits at first parity of New Zealand white female rabbits as affected by heat stress and its alleviation under Egyptian conditions. Tropical Animal Health Production. 33: 451-462.

Marai I.F.M., El-Sayiad Gh. A. and Ayyat M. S. 1994. Some blood and milk constituents as affected by breed and pregnant stage in rabbits. Options Mediterraneennes, 8: 475-487.

Ovimaps, 2014. Ovi location map; Ovi earth imagery date; March 5th, 2014.
Rao, M.V. and Sharma P. S. 2001. Reproductive effect of Vitamin E against mercury chloride reproductive toxicology in male mice. Reproductive Toxicology. 15(6): 705-12

S.A.S 2002. Statistical Analysis System Institute, User's Guide. $6^{\text {th }}$ Edition. North Carolina, USA

Sahin, K. and Kucuk, O. 2001. effect of vitamin $\mathrm{E}$ and $\mathrm{C}$ on performance, digestion of nutrients and carcass characteristics in Japanese quail reared under heat stress $\left(34^{\circ} \mathrm{C}\right)$ Journal of American Physiology and Animal Nutrition, 85: 335-342

Yassein. S. A. Sekena H. A., El-Mallah G. M. and Nagwa A. M. 2011. Response of growing rabbits to feed restriction and some additives on performance, carcass and hepatic gene expression under Egyptian Summer Conditions. Journal of Agricultural Science (3) $2: 45-55$

Received: 4th September, 2017 Accepted: 30th November, 2017 